\section{Jurnal Kimia Sains dan Aplikasi Journal of Scientific and Applied Chemistry}

Journal homepage: http://ejournal.undip.ac.id/index.php/ksa

\title{
Synthesis and Characterization of $\mathrm{Ag} @ \mathrm{C}-\mathrm{TiO}_{2}$ Nanocomposite for Degradation of Sasirangan Textile Wastewater
}

\author{
Heny Puspita Dewi ${ }^{a, 1, *}$, Joko Santoso ${ }^{\mathrm{b}, 2}$, Nur Firda Trianda ${ }^{\mathrm{a}, 3}$, Rodiansono ${ }^{\mathrm{a}, 4}$ \\ a Study Program of Chemistry, FMIPA Lambung Mangkurat University Banjarbaru South Kalimantan, Indonesia \\ ${ }^{\mathrm{b}}$ Physics Study Program FMIPA Lambung Mangkurat University Banjarbaru South Kalimantan, Indonesia \\ *Author emails: 1,*.h.puspita20@yahoo.com; 2.jokosantos01507@gmail.com; 3.nufitrian18@gmail.com; 4.rodiansono@ulm.ac.id \\ https://doi.org/10.14710/jksa.22.6.299-304
}

\section{Article Info}

Article history:

Received: $30^{\text {th }}$ June 2019 Revised: $5^{\text {th }}$ November 2019 Accepted: $13^{\text {th }}$ November 2019 Online: $30^{\text {th }}$ November 2019

Keywords:

$@ \mathrm{C}-\mathrm{TiO}_{2}$ nanocomposite, $\mathrm{Ag} @ \mathrm{C}-\mathrm{TiO}_{2}$ photocatalyst; photocatalytic degradation; Sasirangan wastewater

\section{Abstract}

Carbon-titanium oxide nanocomposite (denoted as @C- $\mathrm{TiO}_{2}$ ) was successfully synthesized via hydrothermal method at $150^{\circ} \mathrm{C}$ for $24 \mathrm{~h}$. The $\mathrm{C}-\mathrm{TiO}_{2}$ nanocomposite was furtherly modified by adding an $\mathrm{Ag}$ metal dopant (denoted as $\mathrm{Ag} @ \mathrm{C}-\mathrm{TiO}_{2}$ ) to improve and applied to the photocatalytic degradation of Sasirangan textile wastewater. The composite photocatalysts were characterized by XRD and UV-Vis DRS spectroscopies. XRD patterns showed that $\mathrm{TiO}_{2}$ in @C- $\mathrm{TiO}_{2}$ mainly consisted of a brookite phase, as indicated by a series sharp diffraction peak at $2 \theta=27.2^{\circ}(111), 31.5^{\circ}$ $(121)$ and $55.9^{\circ}(241)$. The calculated band gap energy $\left(E_{\mathrm{g}}\right)$ derived from UV-Vis DRS spectra for $\mathrm{TiO}_{2}$, @C- $\mathrm{TiO}_{2}$, and Ag@C-TiO were $2.95 \mathrm{eV}, 2.54 \mathrm{eV}$, and $2.74 \mathrm{eV}$, respectively. Ag@C- $\mathrm{TiO}_{2}$ photocatalyst was found to be active for the photocatalytic degradation of Sasirangan textile wastewater, as indicated by the change of wastewater color from dark to clear. The quantitative photocatalytic activity of Ag@C$\mathrm{TiO}_{2}$ was evaluated in the degradation of methylene blue, whereas the conversion of methylene blue was $41.3 \%$. The addition of $\mathrm{Ag}$ to $@ \mathrm{C}-\mathrm{TiO}_{2}$ is believed to play an essential role in the enhancement of photocatalytic activity.

\section{Introduction}

Photodegradation is a common method for the treatment of textile dyes before it disposed into the environment using photocatalyst materials, where organic dyes are broken down into smaller compounds in the presence of light (photons), and the reactions are accelerated by using photocatalysts $[1,2]$. One of the most widely used photocatalyst material is $\mathrm{TiO}_{2}$ because it has high photoactivity in the UV region (gap energy of $\mathrm{TiO}_{2}=$ $3.0 \mathrm{eV}$ (rutile), $3.2 \mathrm{eV}$ (anatase)) and had high chemical stability. $\mathrm{TiO}_{2}$ performance can be significantly improved by adding additional material (dopant), both metal and non-metal, which will reduce the energy gap so that the response to UV rays or appears to be increased [3]. There are several studies have been reported on the addition of non-metal dopants such as nitrogen $(\mathrm{N})$, sulfur $(\mathrm{S})$, and carbon (C) to improve the sensitivity of $\mathrm{TiO}_{2}$ towards visible-light resources $[4,5]$. For example, carbon- doped- $\mathrm{TiO}_{2}\left(\mathrm{C}-\mathrm{TiO}_{2}\right)$ with the amount of carbon-doped around $5.2 \% \mathrm{~mol}$ has the lowest bandgap energy 2.3-2.8 $\mathrm{eV}$ [4]. Several previous reports have also shown that C$\mathrm{TiO}_{2}$ catalysts were effective for the photodecomposition of acid orange 7 ( $\mathrm{AO} 7$ ) with 99\% conversion [6]. Teng et al. [7] also reported the conversion of Rhodamine B using a $\mathrm{C}-\mathrm{TiO}_{2}$ catalyst (with a bandgap energy of $2.91 \mathrm{eV}$ ) and 95\% conversion Rhodamine B was achieved under visible-light irradiation.

Utilization of palm oil shell has a big challenge as a raw material in the synthesis of activated carbon since Indonesia is the biggest country in the production of crude palm oil (CPO) with around 38.2 million tons of CPO and 3.05 million tons of palm kernel oil (PKO). Every ton of CPO production, around $6.5 \%$ of palm kernel oil shells, will be generated. Several previous reports have shown that palm kernel oil shells can be transformed into active carbon using the carbonization method at a relatively 
mild temperature [8, 9]. The performances of activated carbon can be improved both in economic value and usedvalue through combination with other active substances, such as semiconductor materials $\left(\mathrm{TiO}_{2}, \mathrm{ZnO}, \mathrm{Fe}_{2} \mathrm{O}_{3}\right)$ produce photocatalyst composite materials that can be used for dye degradation, clean water treatment, and anti-bacterial with the better performance [10]. In addition, active carbon derived-palm oil kernel shell that obtained via chemical activation of $\mathrm{Na}_{2} \mathrm{CO}_{3} / \mathrm{ZnCl}_{2}$ mixture has high specific surface area BET $\left(S_{\mathrm{BET}}\right) 743.71 \mathrm{~m}^{2} \mathrm{~g}^{-1}$ and demonstrated high adsorption capacity for the adsorption of hydrogen sulfides $\left(\mathrm{H}_{2} \mathrm{~S}\right) 247.33 \mathrm{ppm}$ [11].

Sasirangan is a traditional cloth that originally comes from South Borneo, it is similar to Batik, but it has different making process. The Sasirangan industry in South Kalimantan is generally a home industry with traditional processing. Seeing the nature of these industrial activities, most of the craftsmen have not made efforts to treat the generated waste (e.g., wastewater after the coloring process) and directly dispose of it into water bodies. Therefore, it has an impact on the disruption of the life processes of aquatic organisms, and at the same time, can threaten the sustainability of aquatic ecosystems [11]. Moreover, the presence of textile waste in waters can interfere with sunlight penetration and oxygen diffusion into water bodies.

In this report, we describe the synthesis of silverdoped carbon-titanium oxide nanocomposites (denoted as $\mathrm{Ag} @ \mathrm{C}-\mathrm{TiO}_{2}$ ) using a straightforward hydrothermal method which are producing particles with high crystallinity, high purity, homogeneous particle size distribution, and also use low temperatures below $<300^{\circ} \mathrm{C}$ for the reaction. The addition of $\mathrm{Ag}$ aims to increase the photocatalyst's response to both UV and visible light and to increase the stability of the photocatalyst, while activated carbon is added to increase the active surface area of the photocatalyst. $\mathrm{Ag} @ \mathrm{C}-\mathrm{TiO}_{2}$ nanocomposites that obtained will be compared in their characteristics and photocatalytic activity with pure $\mathrm{TiO}_{2}$ and @ $@-\mathrm{TiO}_{2}$. The photocatalytic reaction will be carried out on the degradation of Sasirangan wastewater in a batch reactor system. As a comparison, photocatalytic reactions of commercial dye c.a. methylene blue (MB) under the same reaction conditions.

\section{Methodology}

\subsection{Materials and Method}

The materials used are Sasirangan wastewater, $\mathrm{AgNO}_{3}$ (99\%, Merck), $\mathrm{TiCl}_{4}$ (99\%, Merck), $\mathrm{HCl}$ (37\%, Merck), ethylene glycol (EG) (99.5\%, Merck Millipore), $\mathrm{NaBH}_{4}(95.0 \%$, Tokyo Chemical Industry (TCI)), methylene blue (70.0\%, Tokyo Chemical Industry(TCI)), ethanol (96\%, Merck) and distilled water. The source of radiation in this work is the HIMAWARI T5-8W UV lamp.

\subsection{Synthesis of palm shell charcoal}

The crushed palm shell charcoal is acidified first using $\mathrm{FeCl}_{3} \cdot 6 \mathrm{H}_{2} \mathrm{O}$ overnight. Giving acid is one of the chemical activation methods of charcoal to enlarge the pores of activated charcoal. The acidified charcoal is then filtered and reactivated by heating at $500^{\circ} \mathrm{C}$ for 3 hours to get activated charcoal.

\subsection{Preparation of $\mathrm{TiO}_{2}$ photocatalyst}

$\mathrm{TiO}_{2}$ photocatalyst was prepared using a $99 \% \mathrm{TiCl}_{4}$ solution as a precursor diluted to $2 \mathrm{M} \mathrm{TiCl}_{4}$ by mixing 100 $\mathrm{mL}$ of $99 \% \mathrm{TiCl}_{4}$ and $1 \mathrm{~mL}$ of $37 \% \mathrm{HCl}$ in $350 \mathrm{~mL}$ of distilled water. This mixing produces a $2 \mathrm{M} \mathrm{TiCl}_{4}$ solution which is turbid white and white precipitate is formed, which is thought to be $\mathrm{TiO}_{2}$ deposition:

$\mathrm{TiCl}_{4(\mathrm{aq})}+2 \mathrm{H}_{2} \mathrm{O}_{(\mathrm{l})} \rightarrow \mathrm{TiO}_{2(\mathrm{~s})}+4 \mathrm{HCl}_{(\mathrm{aq})}$

\subsection{Synthesis of @C-TiO 2 and Ag@C-TiO nanocomposite}

The @C- $\mathrm{TiO}_{2}$ nanocomposite was prepared by mixing activated charcoal into a $2 \mathrm{M} \mathrm{TiCl}_{4}$ solution using a 24 -hour hydrothermal reduction method at $150^{\circ} \mathrm{C}$. $\mathrm{Ag} @ \mathrm{C}-\mathrm{TiO}_{2}$ nanocomposites are made by mixing synthesized @C-TiO 2 powder and adding $\mathrm{AgNO}_{3}$. The method used is also the same as the synthesis of @ $\mathrm{C}-\mathrm{TiO}_{2}$ nanocomposites.

\subsection{Catalyst characterization}

Powder X-ray diffraction (XRD) measurements were filed on a Mac Science M18XHF instrument using monochromatic CuK $\alpha$ radiation $(\lambda=0.15418 \mathrm{~nm})$. The XRD equipment operated at $40 \mathrm{kV}$ and $200 \mathrm{~mA}$ with a step width of $0.02^{\circ}$ and a scan speed of $4^{\circ} \mathrm{min}^{-1}(\alpha 1=0.1540$ $\mathrm{nm}, \alpha 2=0.1544 \mathrm{~nm})$.

Analysis ultraviolet-visible diffuse reflectance spectroscopy (UV-Vis DRS) was performed on a UV-Vis Shimadzu 2450 with a dual-beam system at Affiliation Laboratory of Chemistry, Faculty of Mathematics and Natural Sciences (FMIPA), University of Indonesia Jakarta $\mathrm{BaSO}_{4}$ powder was used as standard material. The calculation of bandgap energy $\left(E_{\mathrm{g}}\right)$ was derived from the obtained spectra using a formula of $E_{g}=h . C / \lambda_{C}$, whereas $h$ is Planck constant $\left(4,136.10^{-15} \mathrm{eV} . \mathrm{s}\right), \mathrm{C}$ is light velocity $\left(2,997.10^{8} \mathrm{~m} \cdot \mathrm{s}^{-1}\right), \lambda_{\mathrm{c}}$ is cut-off wavelength $(\mathrm{nm}) . \lambda_{\mathrm{c}}$ was derived from plotted data of absorbance versus wavelength with linear cross-section on the spectra.

\subsection{Photocatalytic degradation of Sasirangan wastewater and methylene blue}

A typical procedure for the photodecomposition of methylene blue (MB) over the $\mathrm{Ag} @ \mathrm{C}-\mathrm{TiO}_{2}$ catalyst is described as follows. A solution of $\mathrm{MB}(5.0 \mathrm{ppm}, 30 \mathrm{ml})$ and $0.15 \mathrm{~g} \mathrm{Ag@C-TiO}{ }_{2}$ were mixed in the glass-tube reactor $(50 \mathrm{ml})$ then immersed in water batch at $60^{\circ} \mathrm{C}$ under UV or visible irradiations (UV or visible lamp sources are $4 \times 8 \mathrm{~W}$ ). The reaction mixture was stirred at $310 \mathrm{rpm}$ for $30 \mathrm{~min}$ to reach the equilibrium point of 
adsorption-desorption. The reaction mixture was irradiated for $120 \mathrm{~min}$ at a reaction temperature of $60^{\circ} \mathrm{C}$ and sampled every $30 \mathrm{~min}$ and analyzed by using Perkin Elmer UV-Vis double beam spectroscopy.

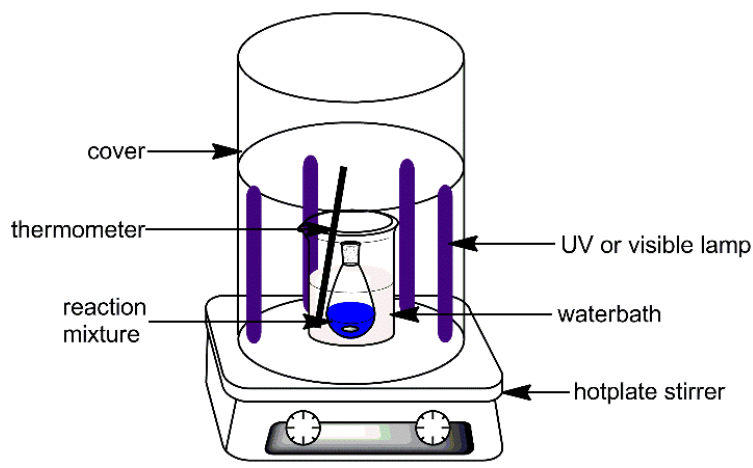

Figure 1. Schematic diagram of the reactor for the photodegradation of methylene blue $\mathrm{Ag} @ \mathrm{C}-\mathrm{TiO}_{2}$ nanocomposites [12].

\section{Result and Discussion}

The synthesized $\mathrm{TiO}_{2}$, @C-TiO ${ }_{2}$, and $\mathrm{Ag} @ \mathrm{C}-\mathrm{TiO}_{2}$ photocatalysts were characterized by using X-ray diffraction, UV-Vis Diffuse reflectance spectroscopy, and the physicochemical properties are summarized in Table 1.

\section{1. $X$-ray diffraction (XRD)}

Figure 2 shows the XRD patterns of the synthesized $\mathrm{TiO}_{2}$, @C- $\mathrm{TiO}_{2}$, and $\mathrm{Ag} @ \mathrm{C}-\mathrm{TiO}_{2}$ nanocomposites. XRD pattern for $\mathrm{TiO}_{2}$ rutile compared to JCPDS card No. 211276, for $\mathrm{TiO}_{2}$ brookite, compared to JCPDS card No. 291360, and for $\mathrm{TiO}_{2}$ compared with JCPDS card No. 21-1272. It can be observed that the brookite phase was predominantly formed in the $\mathrm{TiO}_{2}$ sample. A serial diffraction peak at $2 \theta=25.78^{\circ}, 26.86^{\circ}, 31.24^{\circ}, 40.32^{\circ}$, $44.94^{\circ}, 53.4^{\circ}, 55.98^{\circ}, 63.2^{\circ}, 67.1^{\circ}$, and $68.7^{\circ}$ which can be recognized as $\mathrm{TiO}_{2}$ brookite (120), (111), (121), (022), (032), (320) dan (241), respectively (Figure 2a). Anatase phase was also observed at $2 \theta=53.4^{\circ}$, which also can be assigned as $\mathrm{TiO}_{2}$ anatase (105). A single diffraction peak at $2 \theta=28.10^{\circ}$ that characteristic peaks of $\mathrm{TiO}_{2}$ rutile (110) (Figure 2a). In the case of $\mathrm{C}-\mathrm{TiO}_{2}$ nanocomposite, the main phase of formed- $\mathrm{TiO}_{2}$ in @ $\mathrm{C}-\mathrm{TiO}_{2}$ was brookite which can be easily recognized at $2 \theta=31.24^{\circ}, 45.61^{\circ}$, and $55.98^{\circ}$ as $\mathrm{TiO}_{2}$ brookite (121), (032), and (241), respectively (Figure 2b). Xie et al. [13] also reported that the use of glucose as a precursor of carbon inhibited $\mathrm{TiO}_{2}$ brookite formation.

In the case of $\mathrm{Ag} @ \mathrm{C}-\mathrm{TiO}_{2}$ sample, series new diffraction peaks of $\mathrm{TiO}_{2}$ anatase are clearly observed which can be easily recognized at $2 \theta=24.48^{\circ}, 36.94^{\circ}$, $46.81^{\circ}$ and $53.48^{\circ}$ as $\mathrm{TiO}_{2}$ anatase (101), (103), (201) and (105), respectively. A small peak at $2 \theta=9.70^{\circ}$ was also observed in @ $\mathrm{C}-\mathrm{TiO}_{2}$, which can be attributed to $\mathrm{C}(001)$ phase with tiny crystallite sizes. Moreover, a series diffraction peaks at $2 \theta=37.82^{\circ}, 64.20^{\circ}$, and $77.16^{\circ}$ which can be assigned as $\operatorname{Ag}(111), \operatorname{Ag}(220)$, and $\operatorname{Ag}(311)$, respectively. The crystallite sizes of $\mathrm{Ag}(111)$ metal in $\mathrm{Ag} @ \mathrm{C}-\mathrm{TiO}_{2}$ nanocomposite were $52.8 \mathrm{~nm}$, and the crystallite sizes of the anatase $\mathrm{TiO}_{2}$ (101) phase in $\mathrm{Ag} @ \mathrm{C}$ $\mathrm{TiO}_{2}$ was $11.8 \mathrm{~nm}$.

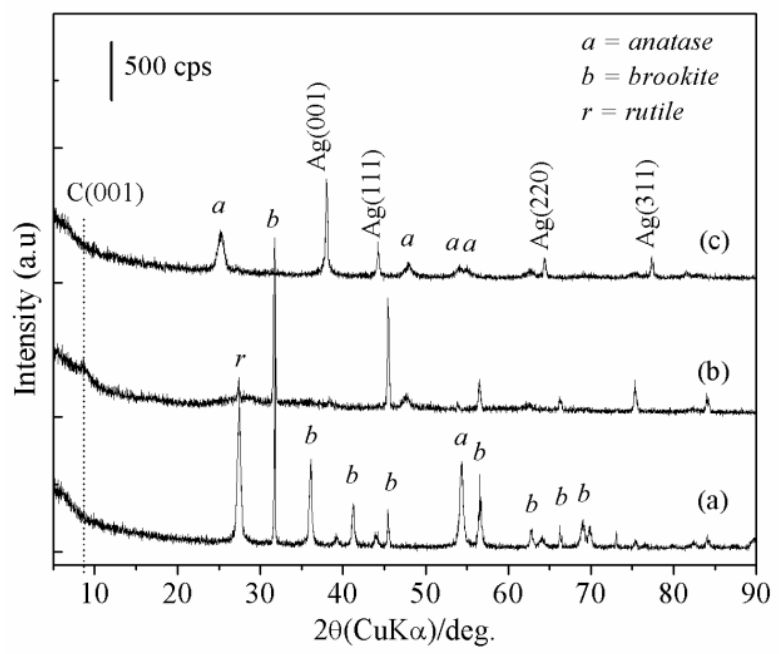

Figure 2. XRD patterns of the synthesized (a) $\mathrm{TiO}_{2}$, (b) $@ \mathrm{C}-\mathrm{TiO}_{2}$, and (c) Ag@C-TiO

Table 1. Physico-chemical properties of $\mathrm{TiO}_{2}$, @C- $\mathrm{TiO}_{2}$, and $\mathrm{Ag} @ \mathrm{C}-\mathrm{TiO}_{2}$ nanocomposites

\begin{tabular}{|c|c|c|c|c|c|}
\hline Entry & Catalysts & $\begin{array}{l}\text { Identified phases } \\
\text { of } \mathrm{TiO}_{2}{ }^{a}\end{array}$ & $D^{b} / \mathrm{nm}$ & $\lambda^{c}(\mathrm{~nm})$ & $E g^{d}(\mathrm{eV})$ \\
\hline 1 & $\mathrm{TiO}_{2}$ & Brookite, rutile & 37.8 & 419 & 2.95 \\
\hline 2 & @C- $-\mathrm{TiO}_{2}$ & $\begin{array}{l}\text { Brookite, rutile, } \\
\text { anatase }\end{array}$ & 35.3 & 483 & 2.54 \\
\hline 3 & $\begin{array}{l}\mathrm{Ag} @ \mathrm{C}- \\
\mathrm{TiO}_{2}\end{array}$ & Anatase & $\begin{array}{l}5.0^{e} \& \\
52.8^{f}\end{array}$ & n.d. & 2.74 \\
\hline
\end{tabular}

${ }^{a}$ Identified main phases of $\mathrm{TiO}_{2}$ compared with JCPDS card. Rutile (JCPDS card No. 21-1276), brookite (JCPDS card No. 291360), and anatase (JCPDS card No. $21-1272$ ). ${ }^{b}$ Average crystallite sizes of $\mathrm{TiO}_{2}$, calculated by using the Scherrer equation. 'Observed cross-section of wavelength $(\mathrm{nm})$, derived from UV-Vis DRS spectra data. ${ }^{~} B$ Band gap energy derived from UV-Vis DRS spectra data. ${ }^{e}$ Crystallite sizes of anatase $\left(\mathrm{TiO}_{2}(101)\right)$ at $2 \theta=25.3^{\circ}$. fCrystallite sizes of $\mathrm{Ag}(111)$ at $2 \theta=38.1^{\circ}$.

\subsection{UV-Vis DRS Analysis}

Figure 3 displays the UV-Vis DRS spectra of each synthesized catalysts. The bandgap energy $(\mathrm{Eg})$ was estimated from the plotting of absorbance (A) versus wavelength (nm) using Tauc equation $\alpha . h . c / \lambda_{c}=B_{d}\left(\right.$ h.c $/ \lambda_{c}$ $\left.-E_{\mathrm{g}}\right)^{\mathrm{n}}$ for allowed transitions ( $\mathrm{n}=2$ for indirect transition, $n=1 / 2$ for direct transition), $h$ is Planck's constant, $c$ is light velocity, and $B_{d}$ is the absorption constant $[14,15]$. The reflectance spectrum profile shows that $\mathrm{TiO}_{2}$, @C$\mathrm{TiO}_{2}$, and $\mathrm{Ag} @ \mathrm{C}-\mathrm{TiO}_{2}$ have absorption regions in visible light areas $(\lambda>400 \mathrm{~nm})$, indicating the doping process that has been carried out was successfully achieved. The values of $\lambda \mathrm{c}$ for each $\mathrm{TiO}_{2}$, @C- $\mathrm{TiO}_{2}$, and $\mathrm{Ag} @ \mathrm{C}-\mathrm{TiO}_{2}$ are $420 \mathrm{~nm}, 487 \mathrm{~nm}$, and $451 \mathrm{~nm}$. The bandgap energy of $\mathrm{Ag} @ \mathrm{C}-\mathrm{TiO}_{2}(2.74 \mathrm{eV})$ produced is relatively small compared to the pure $\mathrm{TiO}_{2}(2.95 \mathrm{eV})$. These results are a good agreement with the previous report of Wang and Lewis [16], who reported the synthesis of @ $@-\mathrm{TiO}_{2}$ 
photocatalysts, which have $E_{g}$ of 2.3 to $2.8 \mathrm{eV}$. Hence, it can be confirmed that the addition of $\mathrm{C}$ material and cocatalyst in the form of Ag can shift the gap energy of the $\mathrm{TiO}_{2}$ band to the visible light region. These results indicate that the addition of dopant Ag significantly shifted the absorption band of $\mathrm{TiO}_{2}$ to the visible region, as indicated by the $E_{\mathrm{g}}$.

\subsection{Photocatalytic degradation}

The $\mathrm{Ag} @ \mathrm{C}-\mathrm{TiO}_{2}$ nanocomposite photocatalytic activity test was carried out through the photocatalytic reaction of waste Sasirangan. The reaction is accomplished in a reactor that has been designed and carried out under UV light and visible light for 120 minutes with stirring at $60^{\circ} \mathrm{C}$. Stirring is done so that both UV and visible light can hit all parts of the photocatalyst evenly. Photocatalyst samples were weighed at $0.15 \mathrm{~g}$,
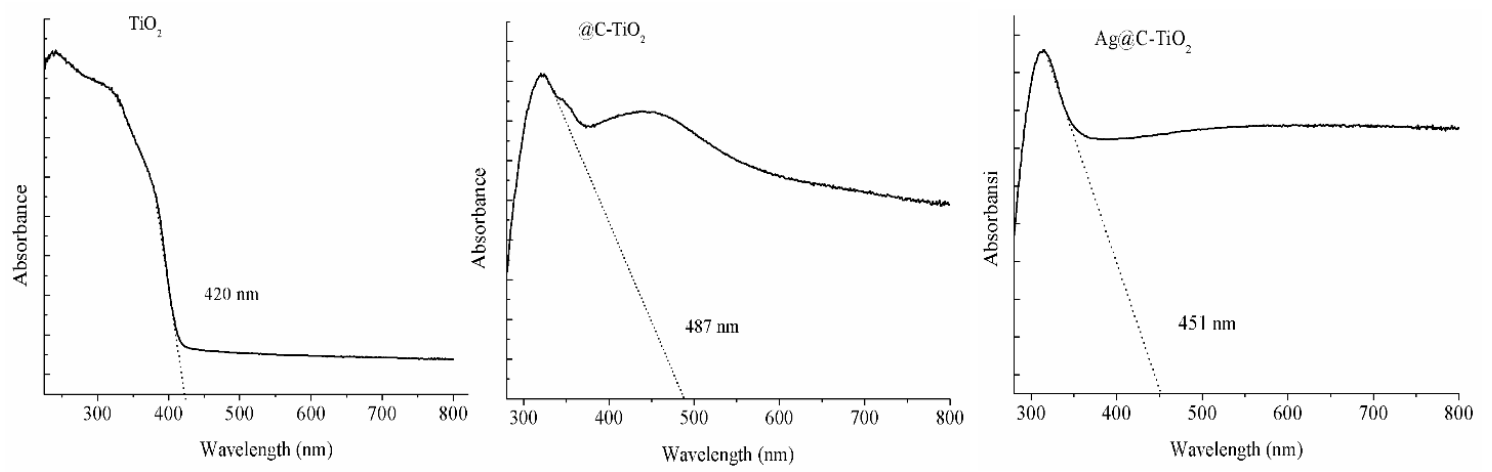

Figure 3. UV-Vis DRS spectra for $\mathrm{TiO}_{2}$, @C-TiO 2 , and $\mathrm{Ag} @ \mathrm{C}-\mathrm{TiO}_{2}$.

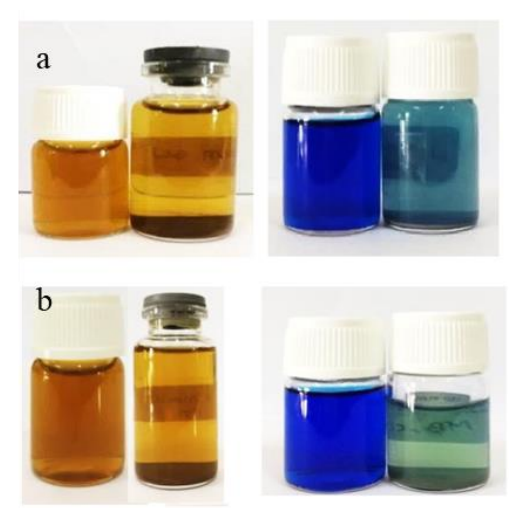

Figure 4 Photo images of photocatalytic reactions of Sasirangan wastewater and methylene blue (MB) using Ag@C$\mathrm{TiO}_{2}$ under irradiation of (a) UV light and (b) Visible light.
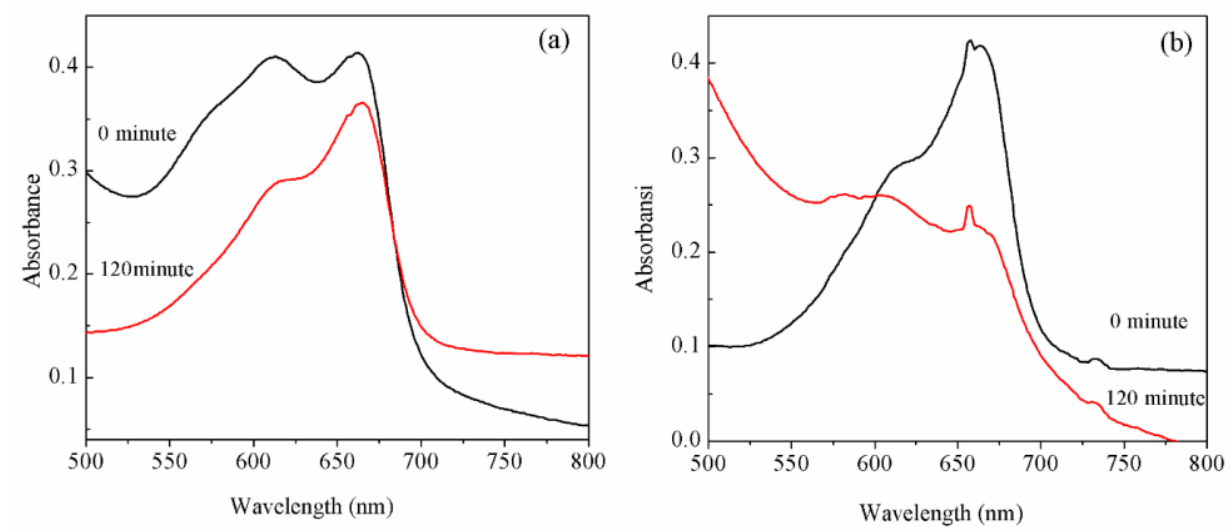

Figure 5. UV-Vis spectra of methylene blue under (a) UV light and (b) visible light after o minutes and 120 minutes. 
Based on UV-Vis analysis data, spectra results (Figure 5) show a decrease in absorbance, which indicates that there is a change in the concentration of the $\mathrm{MB}$ solution when reacted with $\mathrm{Ag} @ \mathrm{C}-\mathrm{TiO}_{2}$ photocatalysts and the results are summarized in Table 1.

Table 2. Results of Photodegradation of MB over Ag@C$\mathrm{TiO}_{2}$ nanocomposite

\begin{tabular}{cccc}
\hline Radiation & $\begin{array}{c}\text { Initial } \\
\text { concentration } \\
(\mathrm{ppm})\end{array}$ & $\begin{array}{c}\text { Final } \\
\text { concentration } \\
(\mathrm{ppm})\end{array}$ & $\begin{array}{c}\text { Conversion } \\
(\%)\end{array}$ \\
\hline Uv light & 3.30 & 2.92 & 11.11 \\
$\begin{array}{c}\text { Visible } \\
\text { light }\end{array}$ & 3.40 & 1.98 & 41.28 \\
\hline
\end{tabular}

The results of the qualitative analysis showed that the addition of $\mathrm{Ag}$ dopants to the @ $-\mathrm{TiO}_{2}$ nanocomposite could degrade Sasirangan waste and methylene blue waste. While the results of quantitative analysis can only be done on a blue methylene solution and cannot be done on Sasirangan waste, as there are many Sasirangan wastes dyes and organic substances, so it is less supportive in quantitative analysis using UV-Vis. Photocatalytic reactions also produce better degradation when done under visible light. This can be seen from the more transparent color changes in the blue methylene solution. This result is also due to the bandgap energy decreasing, where $\mathrm{Ag} @ \mathrm{C}-\mathrm{TiO}_{2}$ has a smaller $E_{g}$ value compared to $\mathrm{TiO}_{2}$. This can be seen from the results of UVDRS characterization.

\section{Conclusion}

Based on the results of research and data processing, it can be concluded that the $\mathrm{Ag} @ \mathrm{C}-\mathrm{TiO}_{2}$ nanocomposite has been successfully synthesized using the hydrothermal method at $150^{\circ} \mathrm{C}$ for 24 hours. The XRD pattern of the $\mathrm{TiO}_{2}$ and $@ \mathrm{C}-\mathrm{TiO}_{2}$ nanocomposite shows that the $\mathrm{TiO}_{2}$ that appears is dominated by the brookite phase (121) while in $\mathrm{Ag} @ \mathrm{C}-\mathrm{TiO}_{2}$, the primary identified $\mathrm{TiO}_{2}$ phases were anatase. The bandgap energy values of $\mathrm{TiO}_{2}$, @C-TiO 2 , and Ag@C-TiO 2 are $2.95 \mathrm{eV}, 2.54 \mathrm{eV}$, and $2.74 \mathrm{eV}$, respectively. $\mathrm{Ag} @ \mathrm{C}-\mathrm{TiO}_{2}$ nanocomposite is active in degrading Sasirangan and methylene blue waste under visible light with a conversion of $41.28 \%$.

\section{Acknowledgment}

This work was financially supported by Program Kreativitas Mahasiswa (PKM) Penelitian FY 2019 from the Ministry of Research, Technology, and Higher Education, Indonesian Government.

\section{References}

[1] Akira Fujishima, Tata N. Rao and Donald A. Tryk, Titanium dioxide photocatalysis, Journal of Photochemistry and Photobiology C: Photochemistry Reviews, 1, 1, (2000) 1-21 https://doi.org/10.1016/S1389-5567(00)00002-2

[2] Miguel Pelaez, Nicholas T. Nolan, Suresh C. Pillai, Michael K. Seery, Polycarpos Falaras, Athanassios G.
Kontos, Patrick S. M. Dunlop, Jeremy W. J. Hamilton, J. Anthony Byrne, Kevin O'Shea, Mohammad H. Entezari and Dionysios D. Dionysiou, A review on the visible light active titanium dioxide photocatalysts for environmental applications, Applied Catalysis B: Environmental, 125, (2012) 331-349 https://doi.org/10.1016/j.apcatb.2012.05.036

[3] Fang Han, Venkata Subba Rao Kambala, Madapusi Srinivasan, Dharmarajan Rajarathnam and Ravi Naidu, Tailored titanium dioxide photocatalysts for the degradation of organic dyes in wastewater treatment: A review, Applied Catalysis A: General, 359, $1,(2009) 25-40$ https://doi.org/10.1016/j.apcata.2009.02.043

[4] H. Wang and J. P. Lewis, Second-generation photocatalytic materials: anion-doped $\mathrm{TiO}_{2}$, Journal of Physics: Condensed Matter, 18, 2, (2005) 421-434 https://doi.org/10.1088/0953-8984/18/2/006

[5] Daimei Chen, Zhongyi Jiang, Jiaqing Geng, Qun Wang and Dong Yang, Carbon and Nitrogen $\mathrm{Co}$-doped $\mathrm{TiO}_{2}$ with Enhanced Visible-Light Photocatalytic Activity, Industrial \& Engineering Chemistry Research, 46, 9, (2007) 2741-2746 https://doi.org/10.1021/ie061491k

[6] Suil In, Alexander Orlov, Regina Berg, Felipe García, Sergio Pedrosa-Jimenez, Mintcho S. Tikhov, Dominic S. Wright and Richard M. Lambert, Effective Visible Light-Activated B-Doped and B,N-Codoped $\mathrm{TiO}_{2}$ Photocatalysts, Journal of the American Chemical Society, 129, 45, (2007) 13790-13791 https://doi.org/10.1021/ja0749237

[7] Feng Teng, Guozhi Zhang, Youqing Wang, Caitian Gao, Lulu Chen, Peng Zhang, Zhenxing Zhang and Erqing Xie, The role of carbon in the photocatalytic reaction of carbon/TiO ${ }_{2}$ photocatalysts, Applied Surface Science, 320, (2014) 703-709

https://doi.org/10.1016/j.apsusc.2014.09.153

[8] Chinedum Anyika, Nur Asilayana Mohd Asri, Zaiton Abdul Majid, Adibah Yahya and Jafariah Jaafar, Synthesis and characterization of magnetic activated carbon developed from palm kernel shells, Nanotechnology for Environmental Engineering, 2, 1, (2017) 16 https://doi.org/10.1007/s41204-017-0027-6

[9] Mohd Adib Mohammad Razi, Adel Al-Gheethi, Mohammed Al-Qaini and Anwar Yousef, Efficiency of activated carbon from palm kernel shell for treatment of greywater, Arab Journal of Basic and Applied Sciences, 25, 3, (2018) 103-110

https://doi.org/10.1080/25765299.2018.1514142

[10] Samira Bagheri, Nurhidayatullaili Muhd Julkapli and Sharifah Bee Abd Hamid, Functionalized Activated Carbon Derived from Biomass for Photocatalysis Applications Perspective, International Journal of Photoenergy, 2015, Article ID 218743, (2015) 1-30 https://doi.org/10.1155/2015/218743

[11] J. Andas, M. L. A. Rahman and M. S. M. Yahya, Preparation and Characterization of Activated Carbon from Palm Kernel Shell, IOP Conference Series: Materials Science and Engineering, 226, (2017) 012156 https://doi.org/10.1088/1757-899x/226/1/012156 
[12] Kurnia Putri, Annisa Annisa, Sadang Husain and Rodiansono Rodiansono, One-pot Synthesis of Carbon-doped $\mathrm{TiO}_{2}$ with Bimetallic Ni-Ag cocatalysts in Photodegradation of Methylene Blue under UV and Visible Irradiation, Bulletin of Chemical Reaction Engineering \& Catalysis, (2020)

[13] Chong Xie, Shenghui Yang, Jianwen Shi and Chunming Niu, Highly Crystallized C-Doped Mesoporous Anatase $\mathrm{TiO}_{2}$ with Visible Light Photocatalytic Activity, Catalysts, 6, 8, (2016) 117 https://doi.org/10.3390/catal6080117

[14] Jiawei Ng, Shiping Xu, Xiwang Zhang, Hui Ying Yang and Darren D. Sun, Hybridized Nanowires and Cubes: A Novel Architecture of a Heterojunctioned $\mathrm{TiO}_{2} / \mathrm{SrTiO}_{3}$ Thin Film for Efficient Water Splitting, Advanced Functional Materials, 20, 24, (2010) 42874294 https://doi.org/10.1002/adfm.201000931

[15] Ya-Wen Zhang, Rui Si, Chun-Sheng Liao, Chun-Hua Yan, Chao-Xian Xiao and Yuan Kou, Facile Alcohothermal Synthesis, Size-Dependent Ultraviolet Absorption, and Enhanced CO Conversion Activity of Ceria Nanocrystals, The Journal of Physical Chemistry B, 107, 37, (2003) 10159-10167 https://doi.org/10.1021/jp0349810

[16] Hao Wang and James P. Lewis, Effects of dopant states on photoactivity in carbon-doped $\mathrm{TiO}_{2}$, Journal of Physics: Condensed Matter, 17, 21, (2005) L209-L213 https://doi.org/10.1088/0953-8984/17/21/lo1 